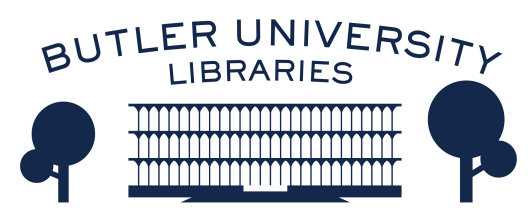

Journal of Hindu-Christian Studies

Volume 7

Article 6

January 1994

\title{
The Dalits, Religions and Interfaith Dialogue
}

A.M. Abraham Ayrookuzhiel

Follow this and additional works at: https://digitalcommons.butler.edu/jhcs

Part of the Religion Commons

\section{Recommended Citation}

Ayrookuzhiel, A.M. Abraham (1994) "The Dalits, Religions and Interfaith Dialogue," Journal of HinduChristian Studies: Vol. 7, Article 6.

Available at: https://doi.org/10.7825/2164-6279.1094

The Journal of Hindu-Christian Studies is a publication of the Society for Hindu-Christian Studies. The digital version is made available by Digital Commons @ Butler University. For questions about the Journal or the Society, please contact cbauman@butler.edu. For more information about Digital Commons @ Butler University, please contact digitalscholarship@butler.edu. 


\title{
The Dalits, Religions and Interfaith Dialogue
}

\author{
A.M. Abraham Ayrookuzhiel \\ The Christian Institute for the Study of Religion and Society \\ Bangalore
}

THE DALITS OF India who follow different religious traditions are beginning to come together these days as one people. While their main concern is to fight economic, political and cultural marginalization, what it means to the religions to which they belong is the question raised in this paper. In order to answer this, we should first have an idea of the kind of questions and problems they raise with respect to different religions. Thereafter we can proceed to some of the implications of this process for interfaith understanding and cooperation.

\section{The Dalits and the Traditional Hindu Heritage :}

\section{A. The Stand of the Dalit Liberation Movement}

In the literature of Dalit liberation and ideology their writers and poets declare war on Hinduism.

\section{I ask for}

my rights as a man

Each breath from my lungs

sets off a violent trembling

in your texts and traditions

your hells and heavens

fearing pollution

I will uproot the scriptures like railway tracks

Burn like a city bus your lawless laws ${ }^{1}$

They explain these ideas through short stories and other literary forms available to them to reach the Dalit masses. The following is an excerpt from a short story in
Marathi in which the religious roots of caste consciousness in the popular Hindu mind is brought out in clear terms. The scene takes place at the threshing floor of a farmer, Bapu Patil, a caste Hindu. The author of the story is a young educated Dalit boy. His grandfather Yetalya, an elderly Dalit, addresses the Patil as "Anna", a term of reverence:

Yetalya: How could you say that, Anna? This Yetalya is certainly not one of those claiming equality. How can one, in that case, account for God's creating religion and castes?

Bapu Patil: Come on, don't you know that the rain-god got enraged because you the Mahars and Mangs - have profaned religion, and abandoned caste, have defiled Lord Vithoba of Pandharpur. How else can you account for the drying up of the Chandrabhaga river?' [Bapu Patil added insult to injury.]

Author: I could take it no more. I felt my cheeks burning. But I quelled my temper and, cutting Bapu Patil short in the middle of his fiery tirade, burst out, "Patil, will you kindly tell me what you meant when you accused us of forgetting religion, abandoning our caste and of polluting the god? And if a religion can't tolerate one human being treating another simply as a human being, what's the use of such an inhumane religion? And if our mere touch pollutes the gods, why were the Mahars and Mangs created at all? And who, may I know, who indeed, created them? And would you please tell me the name of the god whom the Mahars and Mangs can claim as their own?"2 
These Dalits who follow Dr B.R. Ambedkar are convinced that they cannot redeem their self-dignity and humanity remaining within Hinduism. Some of them advocate conversion to Buddhism and exhort their followers to stop worshipping Hindu gods and observe Hindu beliefs and practices. ${ }^{3}$ Others exhort the Dalits to follow a secular rational path as all religions are instruments of social control and political manipulation in the hands of the powerful and well-to-do sections in every religion.

\section{B. The Stand of Traditional Academic and Religious Circles}

The traditional academic and religious writers both in this country and abroad consider the Dalit traditional religion as part of the Hindu heritage, though they admit that their religion still preserves certain distinctive ethnic and religious cultural features. Historically this is justified in the sense that dominant brahminical religion as it evolved over the centuries subjugated and absorbed many primeval tribal groups with their gods, goddesses, religious rituals and customs along with their sacred groves. Priests of the dominant brahminical tradition wove new myths by identifying them with one of the chief or minor deities in their tradition, or made them wives, children or vehicles of their gods. ${ }^{4}$ For instance, the tribal god or Orissa became identified with Vishnu, Murugan of Adidravidians became identified with Skanda of the North Indian traditions, Ayyanar of Chattan of the tribals in the Western Ghats with its Buddhist associations became Sastha of Sabarimala, born of two male gods: Vishnu and Siva, according to brahminical myths in the Puranas. This religious hierarchical subordination was a complementary historical process to the concerned tribal groups' political and economic subjugation. ${ }^{5}$ Some of the authors call this historical process "Hindu imperialism" or "Brahmin internal cultural colonialism", because through this process the concerned tribal groups or a section of them not only lost their social autonomy and economic independence but also their religio-cultural self-identity as a separate group by losing control over their gods, places of worship and the right to administer to their own people's religious needs. Furthermore, many of them internalized brahminical versions of myths relating to this historical process and voluntarily accepted demeaning ritual roles in village festivals, temple rituals and domestic rites corresponding to a servile class in a semi-feudal economy.

\section{The Present-day Situation of the Dalits within Hinduism}

The definition of the Scheduled Castes (Dalits) as Hindus by the Government, its policy of extending the benefits of reservation to Hindu Dalits, the inclusion of popular Dalit shrines under the State Devaswom boards in which Hindu Dalits have nominal representation, the renovation of Dalit places of worship by the Hindu Mutts and organizations, the deep psychological attachment of the Dalits to Hinduized gods of their early tribal days, the similarity of some of their customs and rituals with those of the rest of the Hindu population make a large section of the Dalits believe that they are in fact Hindus; and they participate in Hindu festivals and rituals in varying degrees.

Hindu political and cultural organizations like the Bharatiya Janata Party, Vishwa Hindu Parishad, Rastriya Swayam Sevak Sangh, Bharat Sadhu Samaj, etc. are also very keen to keep the Dalit population within the Hindu fold because of the political weight it will add to the Hindu community. Given the Government's political and economic patronage and traditional religio-cultural practices of the Dalit masses and their low level of awareness, it is difficult for them to understand the stand of Dr B.R. Ambedkar that unless substantial changes take place within Hindu theology, worship practices and nature of the priesthood, it is impossible 
for the Dalits to redeem their human dignity within Hinduism.

\section{The Dalits and Other Religious Traditions}

In the course of history the Dalits embraced other religions like Islam, Sikhism, Christianity and Buddhism in their search for freedom and human dignity. Much of these conversions took place when these religions offered political patronage to the helpless Dalits. Even in the case of their conversion to Buddhism, it was part of the political mobilization of the Dalits under the leadership of B.R. Ambedkar which made them accept his ideology of conversion as a necessary part of acquiring self-healing and getting rid of the stigma as untouchables.

There was another type of religious movement among the Dalits in history. These were around untouchable and lowercaste saints who condemned caste practices and preached a religion of interiority and common humanity. Ravidasis, Kabir Panthis, Dadu Panthis, Satnamis, Valmikis and scores of groups following the teachings of less well-known saints in different regions of the country belong to this type. While the Dalit Liberation Movement recognizes the fact that the problems of the Dalits cannot be solved without their sharing political, economic and cultural power in the wider society, none of these religions by themselves offer an avenue in that direction. On the contrary, caste-cultural differences coupled with class factors mark out the Dalit communities in all the major religious traditions. Generally speaking, both political and religious leadership in all the major nonHindu religious traditions lies with the nonDalit sections of the respective community. Even when a particular religious community - such as a sect within Christianity - is made up of 100 percent Dalits, the class and educational differences of the leadership make it impossible for it to align itself completely with the interests of the Dalit masses.

This, in general outline, is the socio- political background of the Dalit Liberation Movement's attempt to bring about Dalit national solidarity irrespective of the religious traditions they belong to. At the same time they recognize that the Dalit masses may continue to profess different religions. Therefore it is necessary in the context of their common struggle for liberation that those who belong to different religious traditions understand each other's religion as well as the problems they face within it to build a national solidarity of the Dalits as members of one oppressed group. The question is what this approach means to the concern of Interfaith Dialogue.

\section{E. The Dalits and Interreligious Dialogue:}

1. First of all the Dalits are very critical of much of what goes on in the name of Interreligious Dialogue. I quote here just one example of such criticism made by a very distinguished Dalit Supreme-Court lawyer.

When a paper was circulated in the World Conference on Religion and Peace (IV Ássembly) held at Nairobi, Kenya, in 1984, Hindu and Jain delegates from India threatened to walk out if the word Untouchability was not deleted. One member went so far as to threaten to go on hunger strike if the issue was raised in the conference. Indian members of the W.C.R.P. issued a statement which was published in all the national papers published from Delhi stating that there is no untouchability in India. "Untouchability was a thing of the past", the spokesman asserted.

In the $\mathrm{V}$ Assembly held at Melbourne, Australia, in January 1989 through the clever manipulation of Hindu and Jain members of the W.C.R.P. (India), the word "untouchables" was substituted by "marginalized people" in the declaration issued at the end of the conference. They wanted to give an impression to the world that the only disability or difficulty that the deprived and disadvantaged people in India suffer from is poverty, which in fact is a gross 
misrepresentation of facts. Poverty of a Brahmin, or for that matter, any uppercaste man arouses sympathy but the poverty of an untouchable arouses hatred and hostility owing to the deeprooted prejudice inculcated by religion. ${ }^{6}$

2. The Dalits' approach to dialogue centres around their liberation and humanization. The Dalit Movement's approach to religious dialogue is that "the Sabbath was made for man, not man for the Sabbath", a stand advocated by Dr B.R. Ambedkar who has set the direction of Dalit liberation. In dialogue circles in India it is Dr M.M. Thomas who has consistently argued for a similar approach in the praxis of interreligious dialogue. According to him the most fruitful area of interfaith communication and cooperation will be in the area of humanization of our society. One hopes that such an approach might lead to a self-renewal of all our religions as the followers look at their religious beliefs and practices from the point of view of justice, social equality and freedom. As the Dalits belong to different religious traditions, these questions have to be raised in all the religions in the context of dialogue. It gives to the followers of these religions an opportunity to develop a new hermeneutic of their respective scriptures, ritual practices and social ethics.

Historically the religion preached by the Dalit and the lower-caste saints does provide the necessary critique of existing casteconsciousness among the followers of different religions in India. Though much of these utterances and songs were originally made against the brahminical priestly tradition, they apply with equal force to other religions as well. I shall give some examples of such religious teachings as these will be questions uppermost to the Dalits in any form of interreligious gatherings.

\section{a. The essential unity of humankind and the oneness of God}

Do rain and wind avoid some men among the rest
Because their caste is low?

When such men tread the earth

Hast seen it quake with rage?

Or does the brilliant sun

Refuse to them its rays?

Oh Brahmans, has our God

E'er bid the teeming fields

Bring forth the fruit and flowers

For men of caste alone?

Or made the forest green

To gratify the eyes

of none but Pariahs?

Oh Brahmans, list to me!

In all this blessed land

There is but one great caste,

One tribe and brotherhood

One God doth dwell above,

And he hath made us one

In birth and frame and tongue. ${ }^{7}$

Patira Kiriyar laments:

When shall our race be one great brotherhood

Unbroken by the tyranny of caste," which Kapila in early days withstood And taught that men were one in times now passed? ${ }^{8}$

God, according to these saints, takes no account of caste or family, of high or low born. He welcomes women, Sudras and Chandalas. $\mathrm{He}$ craves for their love. ${ }^{9} \mathrm{He}$ who calls another "Südra" or "Paraya" is the real Sudra. He is the one worse than a Paraya. Eating flesh does not make one Paraya.

Vemana says:

Why dost again and again abuse a paraiar?

Are not his blood and flesh and thine one?

Of what caste is he who is inmingled with him?

The deity animates his entire works

They do not see that all castes are in fact one. ${ }^{10}$ 


\section{$b$. They condemned the caste in unequivocal terms}

If we look through all the earth Men, we see, have equal birth.

Made in one great brotherhood, Equal in the sight of God.

Food or caste or place of birth

Cannot alter human worth

Why let caste be so supreme?

'tis but folly's passing stream

While the iron age doth last, Men are good in every caste Blustering fools all men despise;

None are good in such men's eyes.

Viler than the meanest race

Is the man before whose face

Others only Sudras are.

Hell for him shall ne'er unbar

Empty is the caste-dispute:

All the castes have but one root

Who on earth can e'er decide

Whom to praise and whom deride?

Why should we the pariah scorn,

When his flesh and blood were born

Like to ours? What caste is $\mathrm{He}$

Who doth dwell in all we see? ${ }^{11}$

\section{c. They rejected the authority of the Vedas} and other Brahminical books

The four Vedas, Six kinds of Shastras,

The many Tantras and Puranas,

The Agamas which speak of the arts,

And various kinds of other books

Are of no use, just in vain.

So dance Snake, dance!

In a status of stone whanged with a chisel

D'ya think there's understanding?

D'ya think the idiots of the world

Have any understanding?

Will a flaw in a pan go away

If you rule it with tamarind?

Ignorance won't go away from the idiots

So dance Snake, dance!

We'll set fire to divisions of caste,

We'll debate philosophical questions in the market place,

We'll have dealings with despised households,

We'll go around in different paths. ${ }^{12}$ d. They cursed the Brahmin priests. Some of the saints compared them to the dogs of the street howling out the vedas, and to whores. $^{13}$ Here are the words of Chokhamela, an Untouchable saint from Maharashtra.

Cursed be their actions, cursed be their thinking

Cursed be their birth and their life!

Cursed be their "Knowledge of the Absolute" - 'tis all but vain talk.

There is neither pity nor forgiveness nor peace in their hearts!

Cursed be those postures and those hairknots,

in vain have they put on an ascetic garb!

Says Cokhā, cursed be the birth of such people:

In the end they will endure the torments of hell! ${ }^{14}$

e. They denounced pilgrimages, ritual purity and called for a religion of purity of mind, compassion and active service.

\section{Against Pilgrimages}

A dog that has gone to Tirupati does not become a lion. A pig that goes to Kāsi is no elephant.

A whore that goes on pilgrimages to Sri Shylam is no modest woman. They will journey on pilgrimages to Kāsi and the bridge of Rameswaram. They can hereby behold piles of stones but not heaven, not even one of them. If thou givest food to Brabmins, they say it will be profitable to thee; if you were to give to dogs where would be the harm (inferiority)? They say that one soul resides (both here and there) in each. ${ }^{15}$

\section{Against ritualism}

Not in the smoke of sacrifice,

Nor in the chant of Vedic hymns

Does God look for the lowly mind

That fitly enters into bliss

The fiery God is found by those

Who lust no more - who feel no pride -

Whose sense close 'gainst sin and self -

Who humbly walk before their God, ${ }^{16}$

The chanting of the four Vedas

The meticulous study of the sacred scripts,

The smearing of the holy ashes,

- And the muttering of prayers, 
Will not lead you to the Lord!

Let your heart melt within you.

And if you can be true to yourself

Then you will join the limitless light

and lead an endless life.

You dumb fools performing the rituals

with care and in leisureliness

Do gods ever become stone?

What can I do but laugh?

Of what use are temples,

And of what use are sacred tanks?

Slavishly you gather to worship

In temples and tanks. ${ }^{17}$

\section{$f$. They denounced the idea of purity and pollution}

"Thou art unclean! O touch me not!" -

They cry. But who can draw the line?

What man was born without a spot?

In each man's flesh sin has a shrine. ${ }^{18}$

- If the pollutions caused by a birth or a death be real, and if the qualities communicated by that touch be destroyed to what end is it for a soul to become a hermit.

- Defilement appears nowhere in the least but exists in our ideas; whoever considers it will see that the beauty of the world is in truth extreme. If thy ignorance depart, wisdom shall shine with thee. ${ }^{19}$

"All the five elements are equally impure The same impurity pervades the whole world! If that be so, what is it which may be called pure or "impure"?

The body itself is the very source of filth!

At the beginning and at the end, it is full of filth: Who is it then who could get pure? I do not know!

Says Cokhā, I myself wonder;

How could anyone ever get rid of impurity?

Who is pure, who is impure?

My Vitțala is beyond both!

Who was ever polluted and by whom?

He alone is totally pure, by His very nature!

The impurity of all the five elements is present in all bodies:

Who can ever be pure in this world?

Says Cokhā, my Vitțala alone is pure.

He the formless - yet standing on the brick!

In impurity they were born, in impurity they died:
Steeped in impurity, all of them passed away! While mourning others, they'll soon fall dead in their turn

Yet, in their foolishness, they do not invoke the Name!

How can they take pleasure in this body of theirs?

In the end, it will remain bare.

Says Cokhā, do not put trust in your body

At the end Yama's noose will fall on your neck! $!^{20}$

\section{Concluding Remarks}

The religion preached by the untouchable and lower-caste saints - many of whom were wandering ascetics without any economic base and political support - never struck institutional roots in India even among the untouchable masses, though small bands of disciples kept their tradition alive in different parts of the country. The teachings themselves remained as folk wisdom in the lower strata of society. They were never a threat or challenge to popular beliefs and practices centred around temples and places of pilgrimage, massively supported by brahminical myths and stories and presided over by Brahmin priests. The poverty, ignorance and lack of education kept the masses, including the untouchables, as superstitious as ever, given to the fear of evil spirits and addicted to rituals of propitiation. The ideas of purity and pollution built into the brahminical literature were naturally internalized, probably because these ideas originated from the tribal past of the people themselves. Brahmin priests only religiously institutionalized them with myths and forms of cult practices to their own advantage.

The anti-brahminical stance of the Dalit literature has not only religio-cultural but also political implications in the democratic political set-up of India today. The traditional worldview of the Dalits, dominated by the fear of evil spirits and ritualism, is being increasingly challenged, not only by the Dalit literature but also by scientific and rational ideas in the realms of 
their economic, social and political life.

One may wonder whether this emerging historical situation of the Dalits with their increasing conscientization, decisive political importance and growing economic base may not lead to a renaissance of all Indian religious traditions. The anti-brahminical stance of the Dalit is a question mark before all Indian religions as all these religions are infected by caste-consciousness to varying degrees. It is here that the religion preached by the Dalit saints comes into focus as they indicate the nature of the religious problem faced by the Dalits, as well as the direction of renaissance and renewal required of them in the context of dialogue. Will it become a focus and an agenda in interfaith dialogue?

\section{Notes}

1 "White Paper" by Sharankumar Limbale, translated by Priya Adarkar, in Poisoned Bread edited by Arjun Dangle, Bombay: Orient Longman, 1992: p.64.

2 .The Poisoned Bread" by Bandhumadhav, translated by Ramesh Dnyate, in Poisoned Bread, op.cit.: p.148.

3 Cf. the additional vows Dr B.R. Ambedkar had recited at the time of his conversion to Buddhism, a practice continued by Dalit Buddhists. For detailed information cf. Bechert Heinz: Buddhismus, Staat und Gesellschaft, vol. 3, Wiesbaden: Otto Harrassowitz, 1973.

4 D.D. Kosambi, The Culture and Civilization of Ancient India in Historical Outline. Vikas Publishing House, 1987 edn.: pp.45-50, pp.168-71.

5 Cf. D.D. Kosambi, op.cit.: pp.171-2; An Introduction to the Study of Indian History,
Popular Prakashan, reprint 1988: p.100;

R.S. Sharma, Indian Feudalism, Macmillan (2nd edn.): pp.1-4; K.A. Nilakanta Sastri, $A$ History of South India, Oxford University Press: pp.101-2.

6 "Epilogue" by Bhagwandas, Advocate in the Supreme Court, in: B.R. Ambedkar, Slavery and Untouchability, which is worse? (Bhagwandas, ed.), 1989: pp.52-3.

7 "The Brotherhood of Man", Kapila, from The Folk-Songs of Southern India, translated and commented upon by Charles E. Gover, Madras: Higginbothams and Co., 1971: pp.168-9.

8 Ibid.: p.159.

9 See fn. 17.

10 Quoted by C.P. Brown, Verses of Vemana, Asian Educational Services, 1986 (1829): pp.210-5.

11 Telugu Folk Song on "Caste", Gover, $o p$. cit.: p.275.

12 Pambatti Cittar, quoted by K. Kailaspathy in his "The Writings of the Tamil Siddhas" in: Karine Schomer and W.H. McLeod (Eds.), The Santa - Studies in Devotional Tradition of India, Delhi: Motilal Banarsidass, 1987: p. 390 .

13 Quoted by Brown, op. cit.

14 "Cokhämelā, an Untouchable Saint of Maharashtra", by Charlotte Vaudeville, in: Ganther D. Sontheimer (Ed.), Bhakti in South Asian Regional Literatures, Heidelberg: South Asia Institute, University of Heidelberg, 1981: p.86.

15 Quoted by Brown, op. cit.: pp.200-1.

16 Gover, op. cit.: p.31.

17 Civavakkiyar, as cited by Kailaspathy, op. cit.: pp.390-1.

18 Gover, op. cit.: p.272.

19 Vemana, op.cit., Verses 861, 870: pp.208: 10.

20 “Cokhämelā ...", op. cit.: p.67. 